\title{
Pembangunan Aplikasi Pengelolaan Data pada Rumah Sakit Berbasis Web
}

\author{
http://dx.doi.org/10.28932/jutisi.v7i2.3696 \\ Riwayat Artikel \\ Received: 17 Juni 2021 | Final Revision: 25 Juli 2021 | Accepted: 29 Juli 2021
}

\author{
Sara Amelia Rosadi ${ }^{\varpi \# 1}$, Andika Wirawan ${ }^{\# 2}$, Sendy Ferdian Sujadi ${ }^{\# 3}$ \\ \# Program studi Sistem Informasi, Universitas Kristen Maranatha \\ Jln. Surya Sumantri No 65, Sukawarna, Kota Bandung, Jawa Barat 40164 \\ 11773029@maranatha.ac.id \\ 21773024 @maranatha.ac.id \\ ${ }^{3}$ sendy.fseit.maranatha.edu
}

\begin{abstract}
Hospital has a variety of facilities and services. Every day there are transactions recorded by the hospital in the form of documentation such as excel. Over time, if the transactions increase, the files that will be stored will be more and more large. Therefore, a website was created that can make it easier to manage data from these files. The web application is created using PHP and integrates with the MySQL database. The main module of the web application created is to import data from an excel file. The expected results from making this website are to make it easier for employees to manage data and view information in the form of tables or graphs. Data collection methods using observation, through interviews with the person in charge from hospital by giving a questionnaire about the interface of the application. Assessment of the results of interface improvements using a questionnaire from Post-Study System Usability Questionnaire version three, totalling 16 questions. The purpose of the User Interface and User Experience analysis is to assess and serve as a guide for improving the display that has been made whether it is in accordance with the standards requested by the hospital.
\end{abstract}

Keywords — hospital data; interface; user experience; user satisfaction rating.

\section{Pendahuluan}

Seiring bertambahnya kemajuan dan perubahan dalam bidang teknologi, informasi dapat diperoleh dengan mudah dan cepat. Sejak adanya teknologi, perkembangan aplikasi web pun semakin pesat dalam membantu kemudahan dalam menyampaikan dan menampilkan informasi [1] [2]. Penggunaan aplikasi web akan banyak menghemat waktu dan tenaga serta dapat menampilkan informasi yang lebih terorganisir. Berbagai industri seperti lembaga, perusahaan, perguruan tinggi telah memanfaatkan penggunaan aplikasi web untuk memudahkan penggunanya [3].

Pada penelitian yang dilakukan oleh Badai Satria Nugraha dengan judul "Rancang Bangun Aplikasi Pengelolaan Data Hasil Penelitian dan Jurnal Berbasis Web pada STIKES Yayasan Rumah Sakit Dr. Soetomo Surabaya", penelitian ini membahas tentang perancangan aplikasi berbasis web untuk pengelolaan data dari hasil penelitian dan jurnal. Dalam pengembangan aplikasi tersebut menggunakan Entity Relationship Diagram (ERD), Flowchart, Database Management System (DBMS) serta bahasa pemrograman seperti PHP. Dengan adanya aplikasi web tersebut, dapat mempermudah dalam hal mengunggah hasil penelitian dan jurnal. Adapun adanya jurnal tersebut, memberikan kami inspirasi mengenai bagaimana gambaran tentang desain dan implementasi sistem pada aplikasi tersebut [4].

Rumah Sakit Kopo Bandung merupakan sebuah lembaga yang bergerak di bidang kesehatan. Berbagai fasilitas dan layanan tersedia di rumah sakit [5]. Ketika melakukan berbagai aktivitas tersebut, terdapat data-data dan informasi mengenai Rumah Sakit Kopo Bandung yang harus disimpan sebagai bentuk dokumentasi. Data-data tersebut disimpan dalam sebuah file dokumen yang saling berkesinambungan. Rumah Sakit Santosa Kopo Bandung menyajikan macam-macam laporan dengan menggunakan Microsoft Excel [6]. File excel ini telah digunakan dari awal rumah sakit dibangun. Dengan bertambahnya data-data yang disimpan mengakibatkan setiap file dokumen ikut bertambah juga. Hal tersebut membuat para pegawai rumah sakit merasa kesulitan saat mengelola file-file tersebut. Terutama ketika para pegawai mencari arsip data dari file excel. Adapun file excel tersebut belum terorganisir dengan baik sehingga membuat para pegawai mengalami kesulitan. 
Dari permasalahan yang ada maka akan dikembangkan aplikasi berbasis web. Laporan excel yang sudah ditampilkan akan mempunyai beberapa fitur seperti create, update, delete, view, dan bisa juga menyimpan data ke database dari file excel tersebut. Selanjutnya, aplikasi web juga akan menampilkan data-data tersebut dapat berupa tabel, grafik atau chart sehingga para pembaca dapat dengan mudah memahami informasi tersebut. Maka dari itu, antarmuka yang dibuat nanti akan memiliki fitur-fitur tersebut.

Tampilan aplikasi web juga akan menggunakan teknik User Experience agar pengguna dapat mudah mempelajari aplikasi web [7]. Dalam implementasi User Experience ini, penilaian standar akan menggunakan teknik rating dari Post-Study System Usability Questionnaire (PSSUQ) versi tiga dengan jumlah 16 soal dan digunakan untuk memperkirakan tingkat kepuasan user pengguna terhadap tampilan web [8].

\section{Metode PENELITIAN}

\section{A. Tahapan Penelitian}

Metodologi penelitian yang digunakan pada website terbagi menjadi dua bagian. Bagian UI/UX [1] [1] menggunakan pendekatan penelitian deskriptif dan dikombinasikan dengan pendekatan kuantitatif agar kedua pendekatan ini dapat saling melengkapi. Proses pembuatan aplikasi web dan basis data menggunakan metode SDLC (System Development Life Cycle), model yang digunakan adalah model waterfall [9].

Berikut metodologi penelitian yang digunakan pada bagian pengerjaan website dan basis data :

1) Analisis : Tahapan ini bertujuan untuk menghasilkan sebuah kebutuhan dari sistem yang akan dibuat. Kebutuhan ini didapatkan dari analisis berupa wawancara yang telah dilakukan sebelumnya.

2) Desain : Tahap selanjutnya menyajikan perancangan desain dari aplikasi seperti erd, use case, activity diagram dan bpmn. Dalam merancang desain ini didasarkan pada analisis sebelumnya.

3) Implementasi : Pada tahapan ini, desain yang sudah dibuat pada tahapan sebelumnya akan dirancang menggunakan bahasa pemrograman yaitu PHP dan basis data yang digunakan adalah MySQL [10].

4) Pengujian: Tahapan ini dilakukan ketika semua tahapan sebelumnya telah dilakukan hingga akhirnya menghasilkan sebuah web yang dapat berfungsi sesuai dengan kebutuhan.

Berikut metodologi penelitian yang digunakan dalam $U I / U X$ ini meliputi:

1) Pencarian dan pengumpulan data: Tahap ini, data dicari dan dikumpulkan dari studi literatur dengan mencari jurnal referensi di internet, observasi dengan melakukan wawancara langsung dengan pihak rumah sakit untuk mengumpulkan informasi-informasi yang dibutuhkan dalam pembuatan penelitian ini, dan yang terakhir adalah kuesioner yang dipakai untuk penilaian tampilan aplikasi yang sudah dibuat. Kuesioner ini diberikan langsung kepada pihak rumah sakit.

2) Analisis untuk pencarian standar dari penilaian $U I / U X$ : Tahap analisis penilaian standar dari $U I / U X$ meliputi [11]:

- Pemilihan evaluator agar dapat mengevaluasi tampilan aplikasi web, penilaian oleh evaluator menggunakan teknik rating dari setiap pertanyaan agar mendapatkan standar penilaian dengan tepat.

- Analisis hasil penilaian berupa rating semoga dapat mengetahui apakah UI/UX pada aplikasi web sudah memenuhi standar atau belum.

3) Desain aplikasi web: Tahap desain aplikasi web dilakukan menggunakan Balsamiq Mockups 3 untuk memberikan sketsa gambar pada prototype yang akan dibangun. Pada tahap ini, dilakukan pembuatan use case dan sketsa tampilan dengan menggunakan Balsamiq Mockups 3 untuk memberikan gambaran terhadap pihak rumah sakit ini tentang bagaimana tampilan dari web yang akan dibuat.

4) Perbaikan sketsa $U I / U X$ : Tahap perbaikan sketsa $U I / U X$ dilakukan berdasarkan analisis dari hasil penilaian $U I / U X$ yang belum memenuhi standar permintaan dari pihak rumah sakit. Pada tahap ini, proses penilaian $U I / U X$ dari pihak rumah sakit dilakukan dengan cara mengisi form penilaian yang sudah disediakan untuk menghitung rata-rata sebelum perbaikan terhadap $U I / U X$ yang diminta dari pihak rumah sakit. Lalu, setelah perbaikan $U I / U X$, pihak rumah sakit akan menilai lagi dengan cara yang sama yaitu dengan mengisi form penilaian yang sudah disediakan.

5) Pembangunan aplikasi web: Tahap pembangunan aplikasi web didasarkan pada tahap desain sketsa yang telah dilakukan sebelumnya dengan sedikit perubahan pada tampilan yang akan dibuat untuk menyesuaikan dengan permintaan dari pihak rumah sakit. Tahap pembangunan ini dilakukan dengan menggunakan PHP Framework yaitu Laravel 8. Untuk tampilannya, menggunakan template yang sudah tersedia yaitu Bootstrap 4. Penggambaran arsitektur/struktur aplikasi web keseluruhan dapat dilihat pada [12] Gambar 1 Arsitektur Aplikasi Web [2] [12] [13] [14]. 


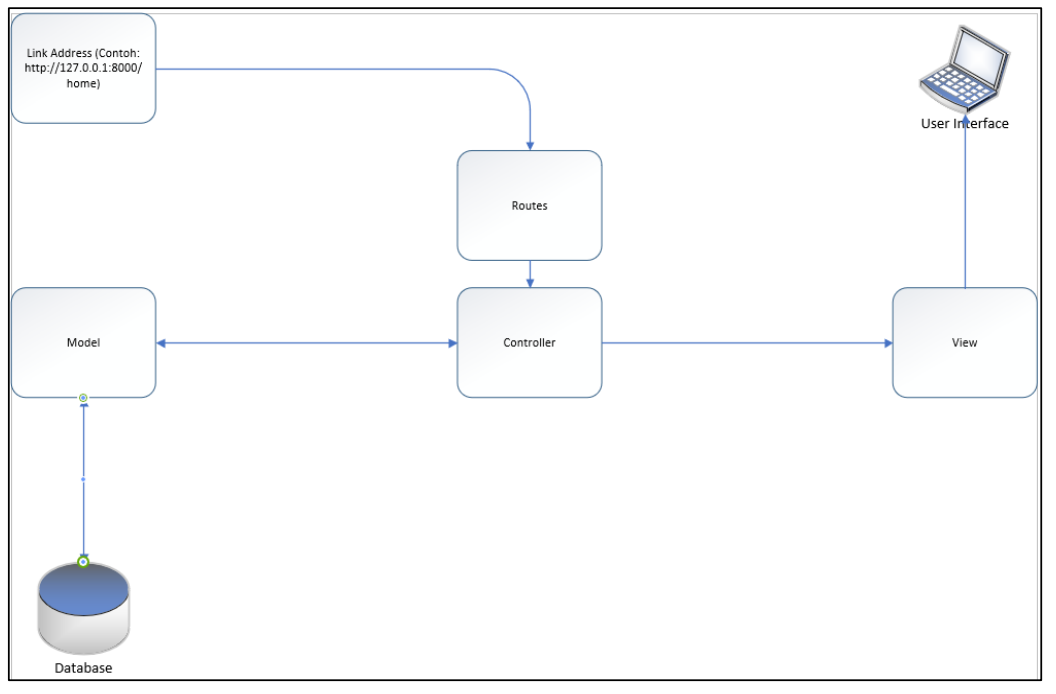

Gambar 1 Arsitektur Aplikasi Web [12]

Pada Gambar 1 Arsitektur Aplikasi Web menjelaskan bahwa arsitektur untuk pembuatan aplikasi menggunakan pola desain Model-View-Controller (MVC). Pada MVC, dibagi menjadi 3 bagian yaitu [15]:

1) Model: Komponen Model adalah semua logika terkait data yang digunakan pada aplikasi. Model mewakili alur data antara komponen View dan Controller atau data yang berada di logika bisnis. Misalnya, objek Pasien akan mengambil informasi pasien dari database, memanipulasinya dan memperbarui datanya kembali ke database atau menggunakannya untuk merender data.

2) Controller: Controller bertindak sebagai komponen yang mengontrol Model dan View untuk memproses semua logika bisnis dan permintaan yang masuk, memanipulasi data menggunakan komponen Model dan berinteraksi dengan View untuk finalisasi logika bisnis. Misalnya, pengontrol Pasien akan menangani semua interaksi dan input dari Tampilan Pasien dan memperbarui database menggunakan Model Pasien. Kontroler yang sama akan digunakan untuk melihat data Pasien.

3) View: Komponen View digunakan untuk semua logika tampilan antarmuka aplikasi. Misalnya, tampilan Pasien akan menyertakan semua komponen tampilan antarmuka seperti textfield, dropdown list, dan komponen input pengguna lainnya. yang berinteraksi dengan pengguna akhir.

\section{B. Tahap Pembuatan Tampilan}

Berikut adalah tahapan-tahapan yang dilakukan dalam pembuatan tampilan:

1) Instal Laravel: Langkah pertama yang harus dilakukan adalah dengan menginstal Laravel dengan menggunakan sistem operasi Windows, maka proses penginstalan Laravel dilakukan dengan menggunakan command prompt. Setelah membuka command prompt, selanjutnya unduh Laravel menggunakan composer. Setelah mengetik perintah untuk mengunduh Laravel pada command prompt, file untuk proyek Laravel akan otomatis terunduh pada terunduh pada direktori yang sudah ditentukan [12].

2) Penggunaan Metode MVC: Di dalam projek Laravel, sudah tersedia folder untuk memisahkan bagian-bagian web, yaitu penggunaan metode $M V C$ (Model, View, Controller). Untuk pembuatan tampilan yang dibutuhkan hanya folder view dan controller, karena folder model digunakan untuk hal yang berurusan dengan database, sedangkan view adalah bagian antarmuka atau bagian depan aplikasi dan controller adalah bagian yang menangani model dan view. Hal pertama yang harus dilakukan dalam pembuatan tampilan menggunakan metode $M V C$ ini adalah dengan membuat route pada file web.php untuk digunakan pada controller. Setelah membuat route, selanjutnya adalah dengan membuat function pada controller untuk me-return view yang ingin ditampilkan. Lalu yang terakhir tinggal membuat tampilan pada folder view sesuai dengan route dan function pada controller yang sudah dibuat [15].

3) Mengimplementasikan Template Bootstrap: Template Bootstrap yang digunakan disini adalah template yang bernama AdminLTE yang dibuat khusus untuk keperluan dashboard admin. Pertama yang harus dilakukan adalah mengunduh file AdminLTE dari internet. Setelah file berhasil diunduh, salin folder di dalam file AdminLTE dengan nama css. img, $j$ s, dan plugins ke folder public di projek Laravel supaya style pada AdminLTE bisa digunakan. Selanjutnya, salin file tampilan yang ingin digunakan ke dalam folder views di projek Laravel. Lalu yang terakhir, ubah tampilan sesuai dengan kebutuhan tampilan aplikasi [16]. 


\section{Analisis Sistem yang akan Dibangun}

Sistem terdahulu masih menggunakan file excel untuk mengelola data secara manual. Sistem yang akan dibangun terdapat dua user yang masing-masing memiliki hak akses. User pertama adalah admin yang akan mengelola data serta informasi yang akan ditampilkan. User kedua adalah pegawai yang hanya dapat melihat informasi pada halaman. Proses utama yang terjadi pada web ini adalah import file excel ke dalam web. Jika pada halaman yang dituju sudah tampil, maka admin dapat melakukan import, tambah, ubah, hapus data dan pegawai hanya dapat melihat informasi pada halaman. BPMN dari aplikasi web yang akan dibuat dapat dilihat pada Gambar 2 BPMN aplikasi web yang akan dibuat [17].

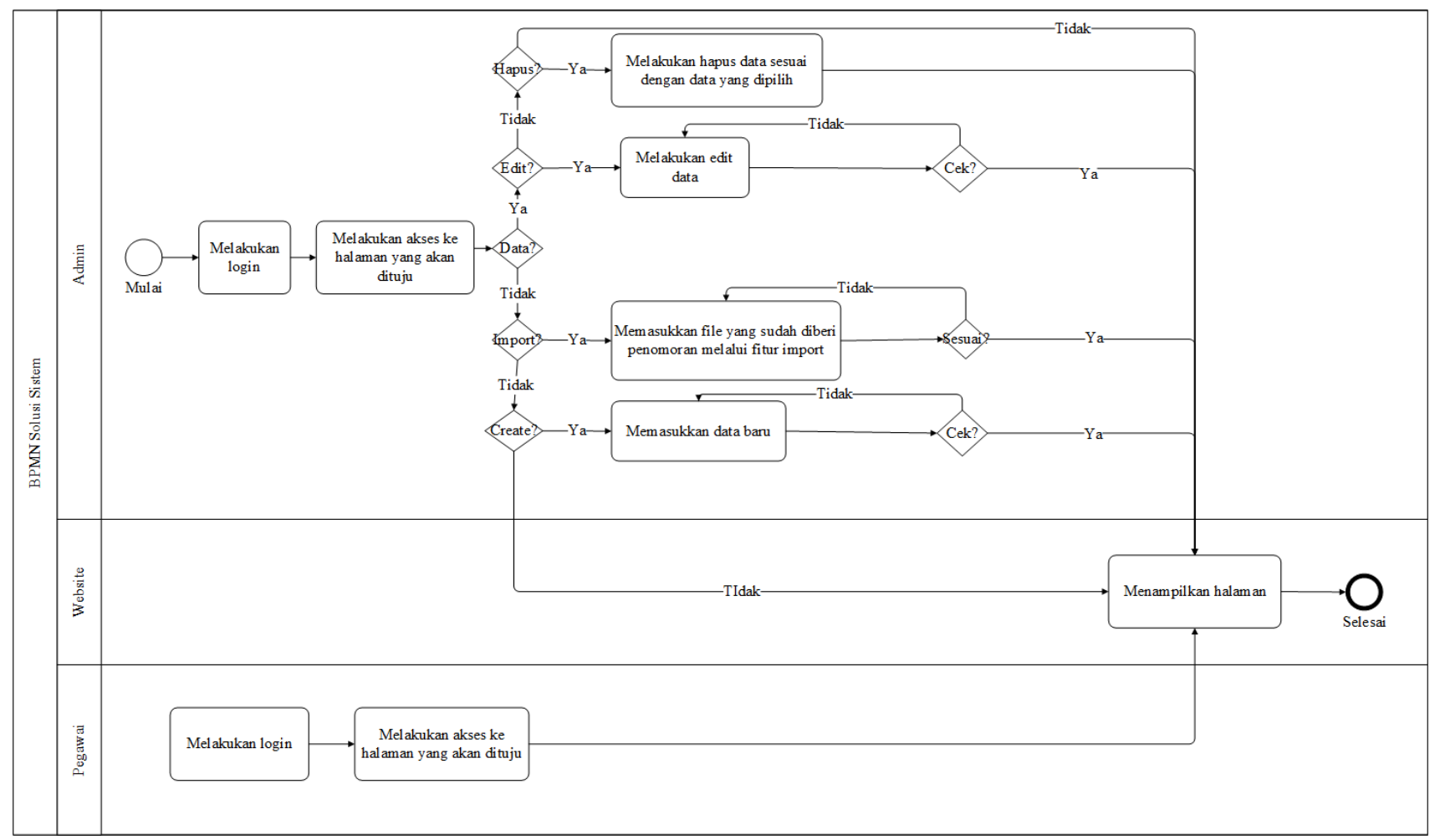

Gambar 2 BPMN aplikasi web yang akan dibuat

\section{Perancangan Sistem}

Pada perancangan sistem ini menggunakan beberapa pemodelan yaitu :

1) Use Case :Gambar 3 menampilkan keterkaitan user pengguna dengan use case atau fitur pada sistem yang akan dibuat pada aplikasi web [18].

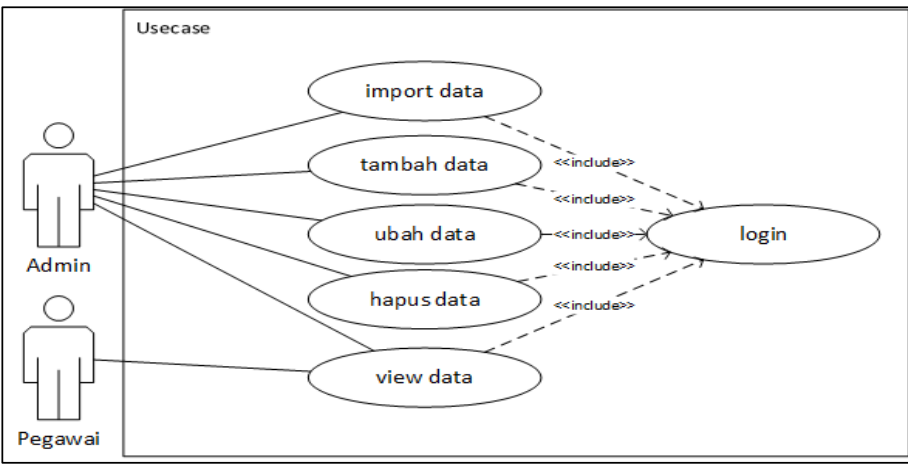

Gambar 3 Use Case Diagram aplikasi web 
2) Activity Diagram: Pada bagian ini akan menampilkan alur aktivitas antara user pengguna dengan sistem yang akan dibuat di aplikasi web. Berikut activity diagram yang dibuat:

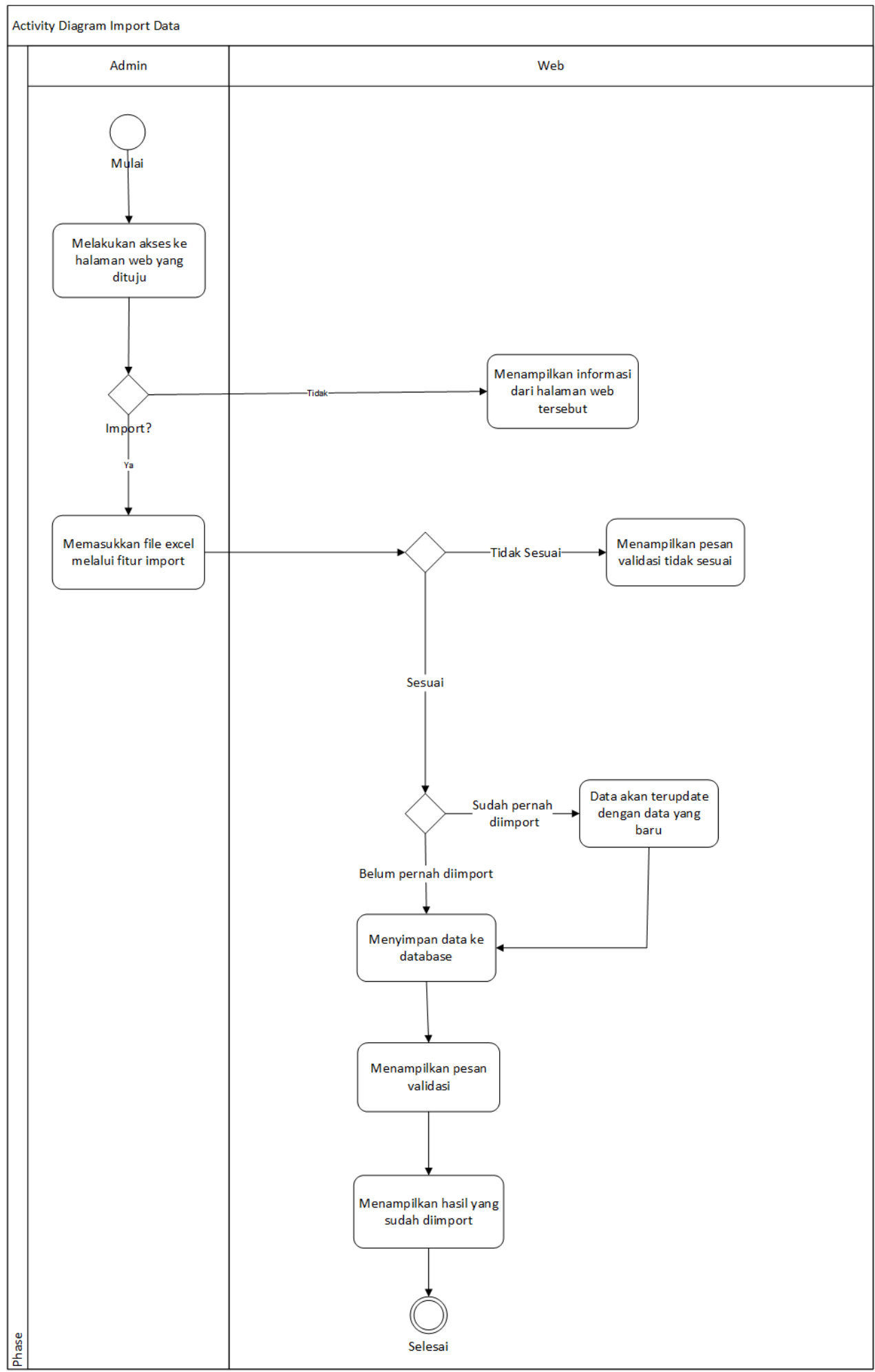

Gambar 4 Activity Diagram Import Data dari File Excel 
Gambar 4 Activity Diagram Import Data dari File Excel, aktivitas akan diawali oleh admin untuk melakukan import data excel yang kemudian data tersebut disimpan kedalam database. Jika akan melakukan import kembali dan memiliki data yang sama, maka data sebelumnya akan terupdate dengan data yang baru. Jika tidak memiliki data yang sama, maka data akan bertambah. Jika file excel yang di-import tidak sesuai, maka akan menampilkan pesan validasi tidak sesuai. Pada proses import ini terdapat pada halaman kunjungan, mutasi, lab, kegiatan, administrasi, inventaris, investasi, listrik, telepon, luas bangunan, sumber data, unit cost dan analisa bpjs, unit cost dan analisa reguler setelah bpjs, unit cost dan analisa manajemen, rekapitulasi layanan, general affair, grafik, perbaikan investasi, price, salary dan sewa gedung.

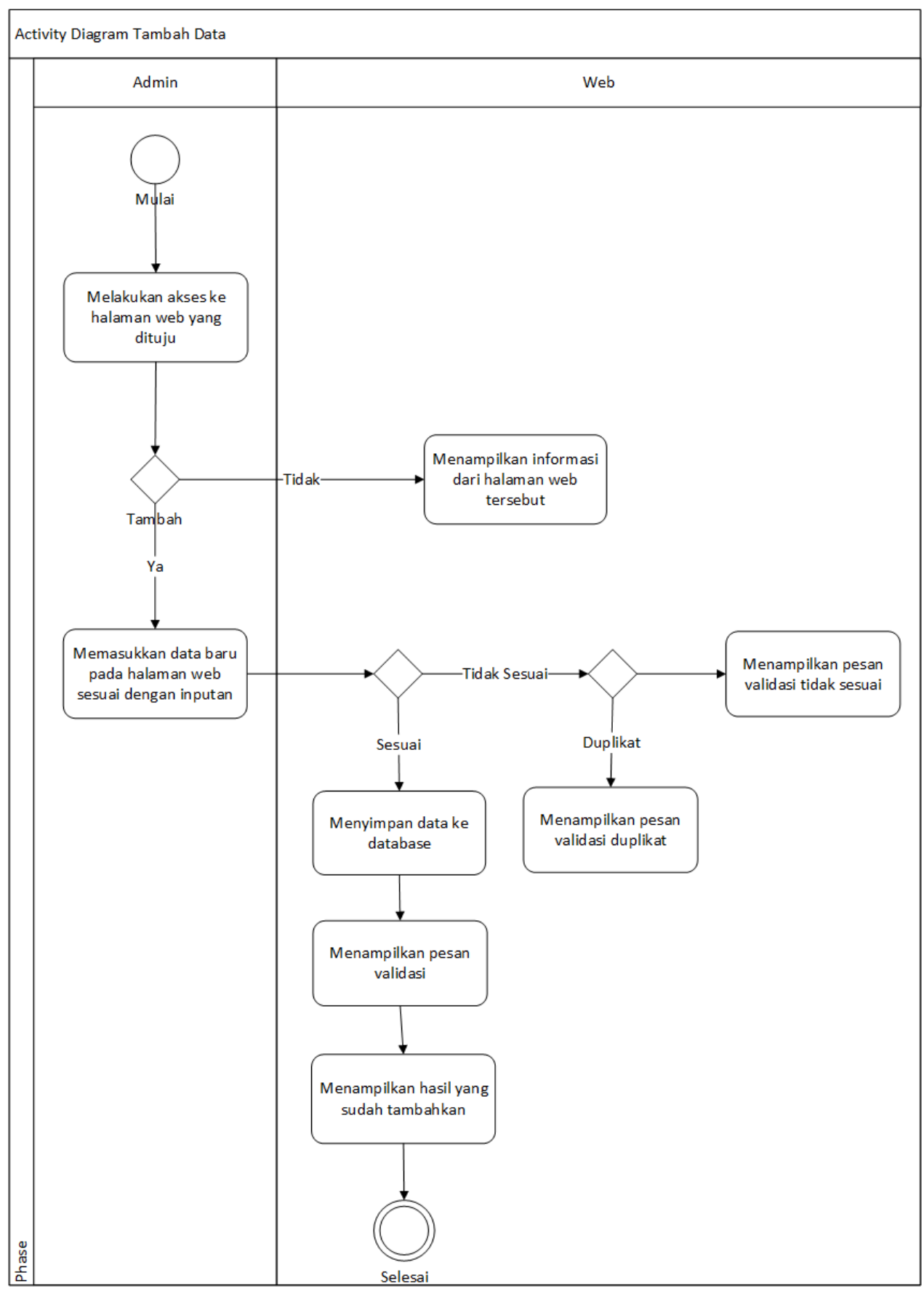

Gambar 5 Activity Diagram Tambah Data 
Gambar 5 Activity Diagram Tambah Data, aktivitas akan diawali oleh admin untuk melakukan penambahan data atau memasukkan data baru pada halaman web yang dituju. Jika pada tambah data terdapat duplikat data dengan data yang sudah ada, maka halaman website akan menampilkan pesan validasi dan data perlu diubah. Pada proses tambah data terdapat pada halaman kunjungan, mutasi, lab, administrasi, inventaris, investasi, listrik, telepon, luas bangunan, grafik dan salary.

\section{E. Sketsa Tampilan}

Berikut adalah beberapa sketsa tampilan untuk pembangunan website:



Gambar 6 Sketsa Login

Gambar 6 Sketsa Login adalah sketsa antarmuka untuk halaman login pengguna. Halaman ini akan tampil pertama kali saat membuka web. Terdapat inputan untuk mengetik username dan password, lalu tombol login, dan ada pilihan jika lupa password, yang dimana jika user pengguna lupa password dengan fitur ini akan diminta memasukan email lalu aplikasi akan mengirimkan prosedur ubah password ke email yang di masukkan di fitur forgot password.

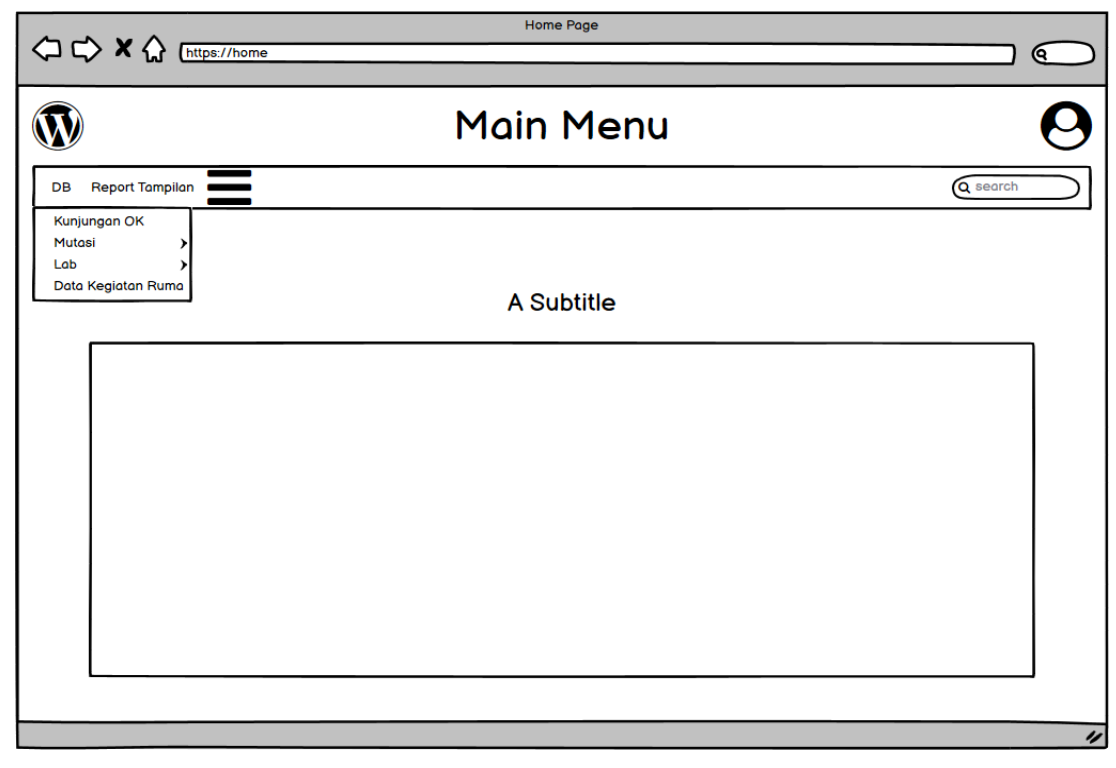

Gambar 7 Sketsa Home 
Gambar 7 adalah sketsa antarmuka untuk halaman home, yang akan tampil setelah user berhasil login ke dalam web. Di halaman home terdapat menu untuk masuk ke dalam halaman laporan, lalu space di tengah bisa untuk diisi dengan pengumuman atau hal lain yang dibutuhkan oleh pihak rumah sakit untuk di tampilkan di halaman home.



Gambar 8 adalah sketsa antarmuka untuk halaman laporan, yang akan tampil setelah user memilih di halaman home laporan apa yang ingin dilihat. Pada halaman laporan ini, sebelum file di import, halaman akan kosong dan hanya menampilkan button untuk import file excel laporan. Terdapat button untuk memilih file dan submit file yang ingin ditampilkan menjadi tampilan web. Lalu setelah user memilih dan submit file excel, akan tampil tabel.

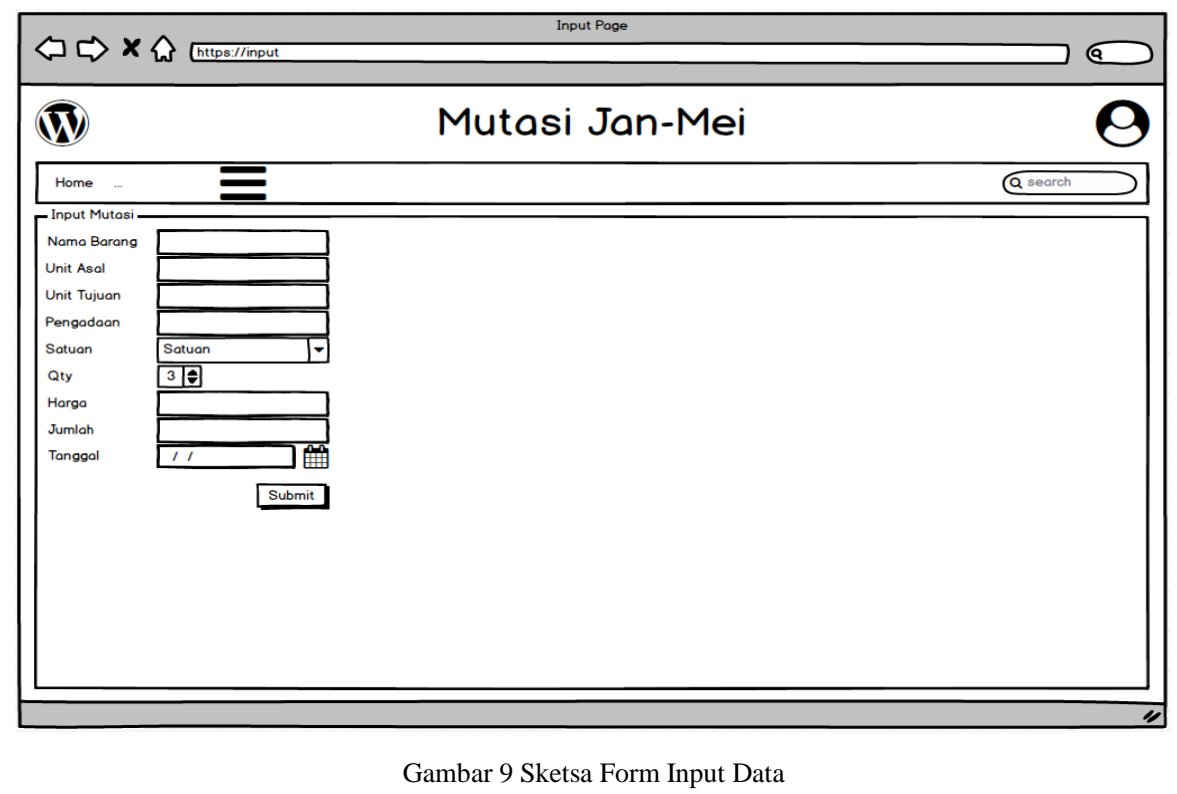

Gambar 9 adalah sketsa antarmuka untuk tampilan halaman form input data yang akan tampil saat user memilih untuk menambahkan data ke dalam tabel. Pada halaman input data ini, hanya berisi form untuk mengisi data yang perlu dimasukkan untuk menambahkan data ke dalam tabel. 


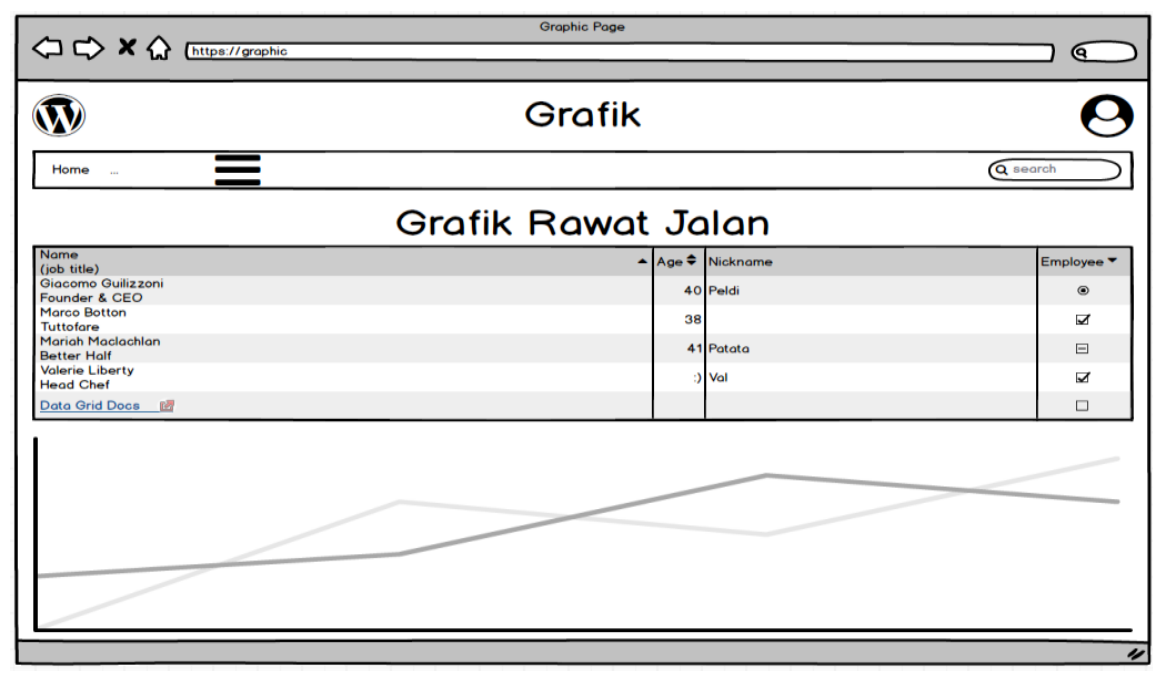

Gambar 10 Sketsa Form bentuk Grafik

Gambar 10 bentuk Grafik adalah sketsa tampilan untuk tampilan grafik. Halaman grafik ini menampilan grafik dimana data dari grafik tersebut adalah data dari tabel grafik yang diperoleh dari file excel yang diberikan oleh pihak rumah sakit.

\section{HASIL DAN PEMBAHASAN}

\section{A. Tampilan Antarmuka}

1) Tampilan Login: Pada Gambar 11 ini akan menampilkan inputan berupa email dan kata sandi yang perlu dimasukkan agar halaman web dapat terbuka. Jika user tidak memiliki akun, maka dapat mendaftar dengan menekan Sign Up.

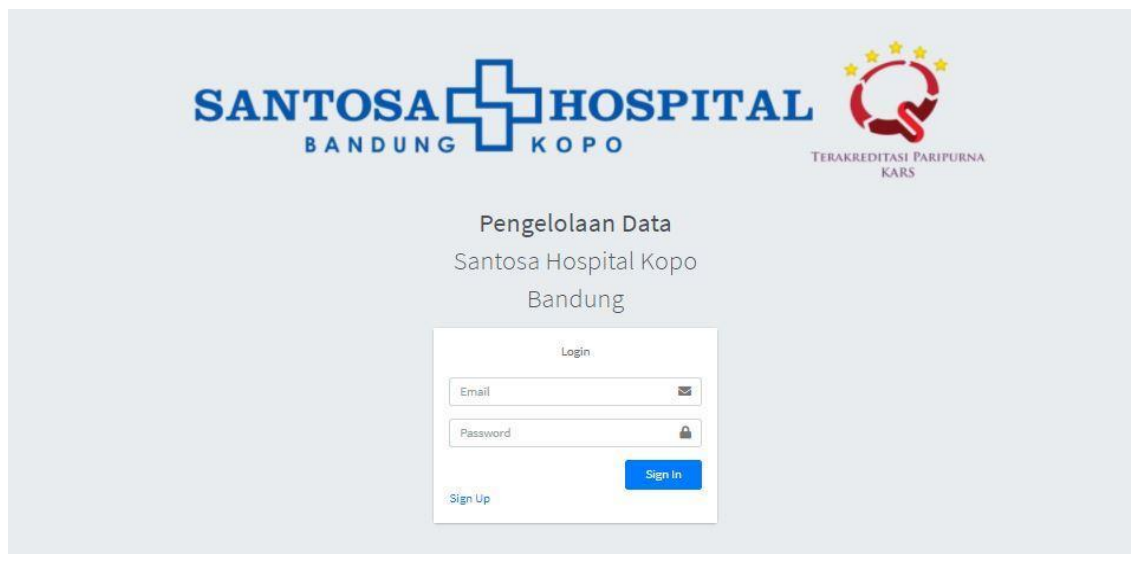

Gambar 11 Tampilan Login

2) Tampilan Home: Pada tampilan home admin dan pegawai ini akan menampilkan profil dari rumah sakit berupa visi dan misi.

a. Admin, Gambar 12 Tampilan Home Admin adalah untuk halaman peran admin dimana menu berwarna gelap. 

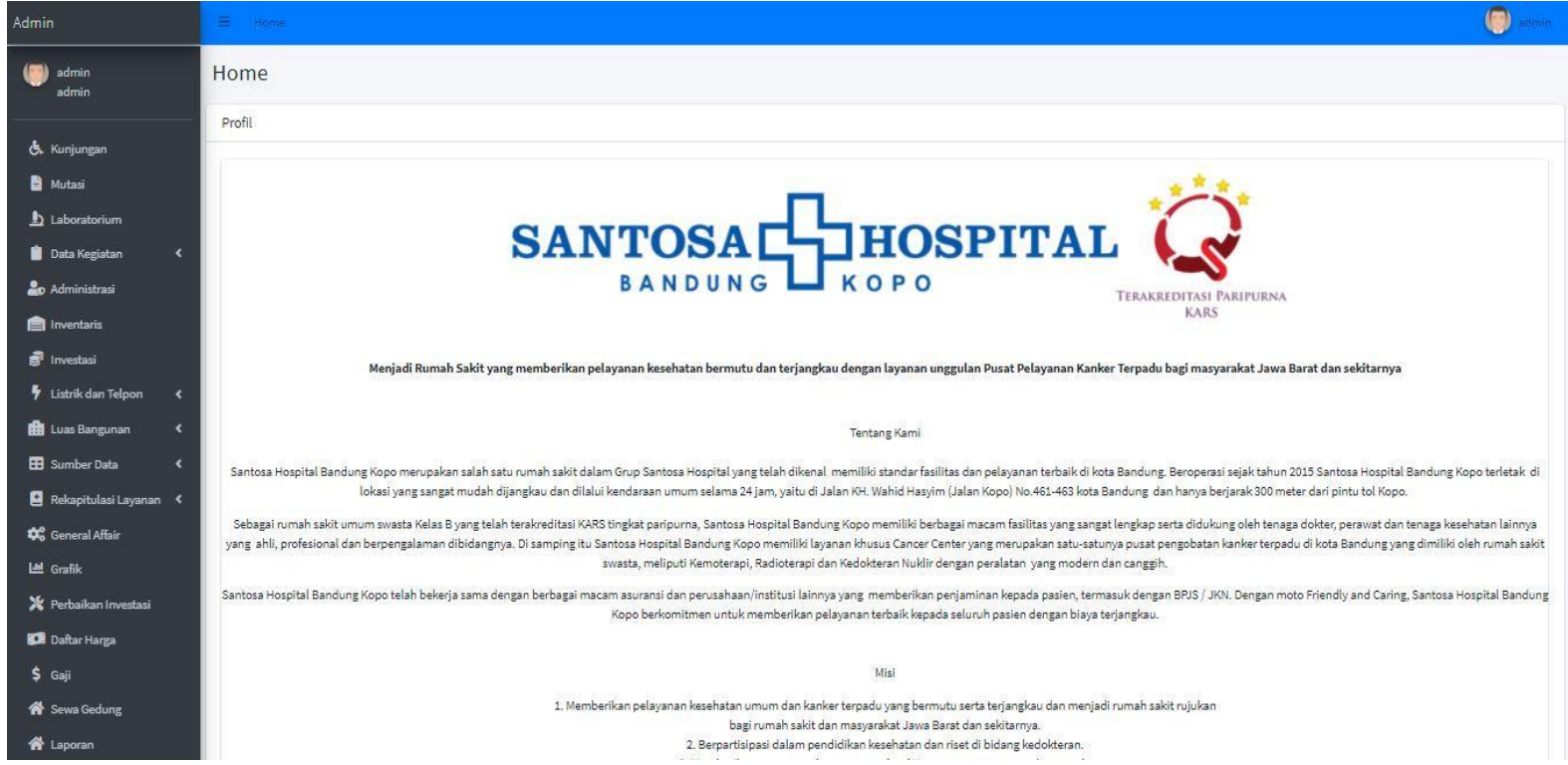

Gambar 12 Tampilan Home Admin

b. Pegawai, Gambar 13 Tampilan Home Pegawai adalah untuk halaman peran pegawai dimana menu berwarna terang.

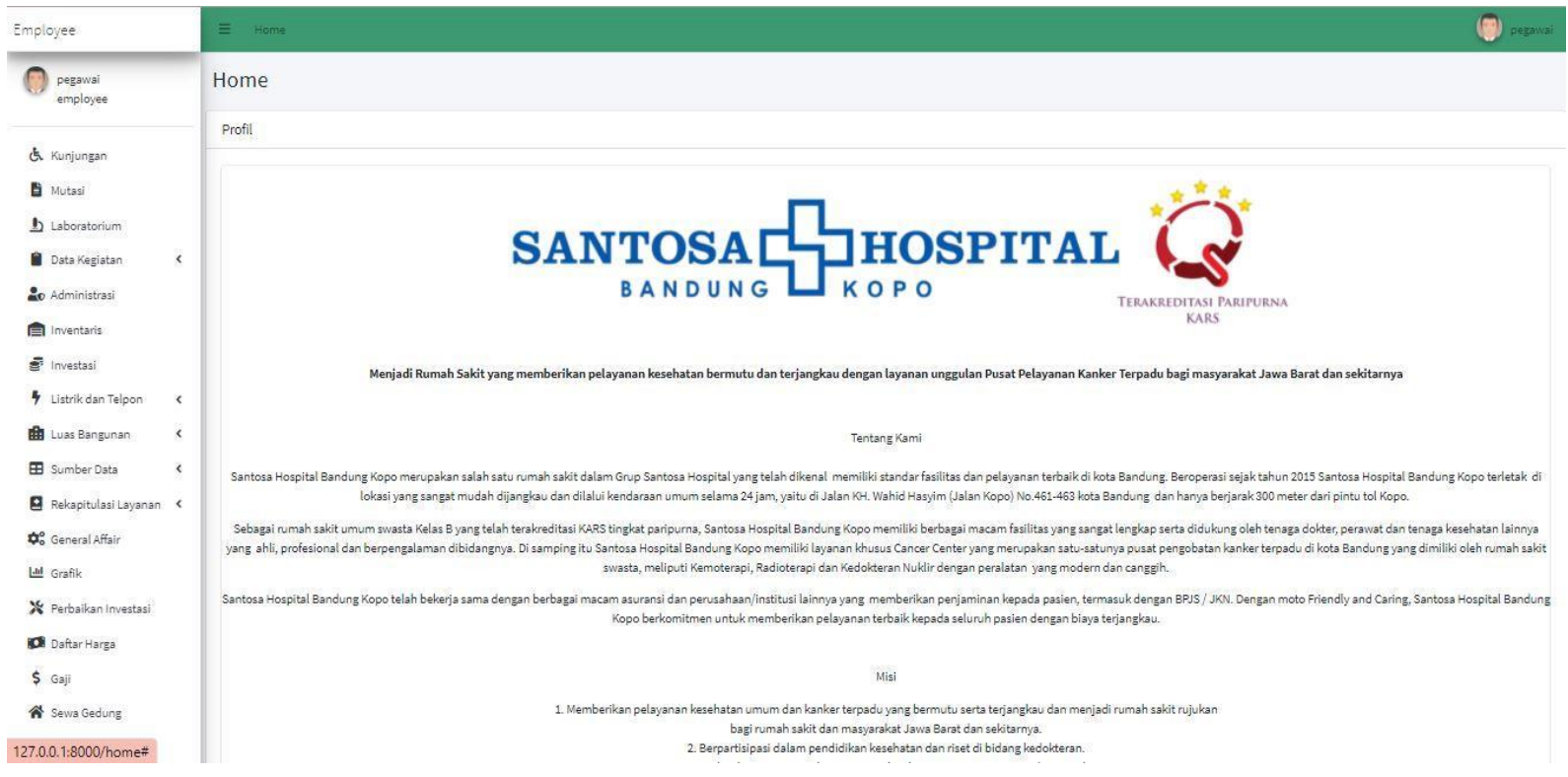

Gambar 13 Tampilan Home Pegawai 
3) Tampilan Halaman Import Data dari File Excel: Gambar 14 adalah contoh tampilan panel untuk memilih file excel yang akan di-import ke aplikasi. Gambar 15 adalah contoh untuk import file excel untuk data lab, pada halaman ini akan menampilkan data dari file yang sudah di import atau ditambahkan sebelumnya.



Gambar 14 Tampilan Form Import

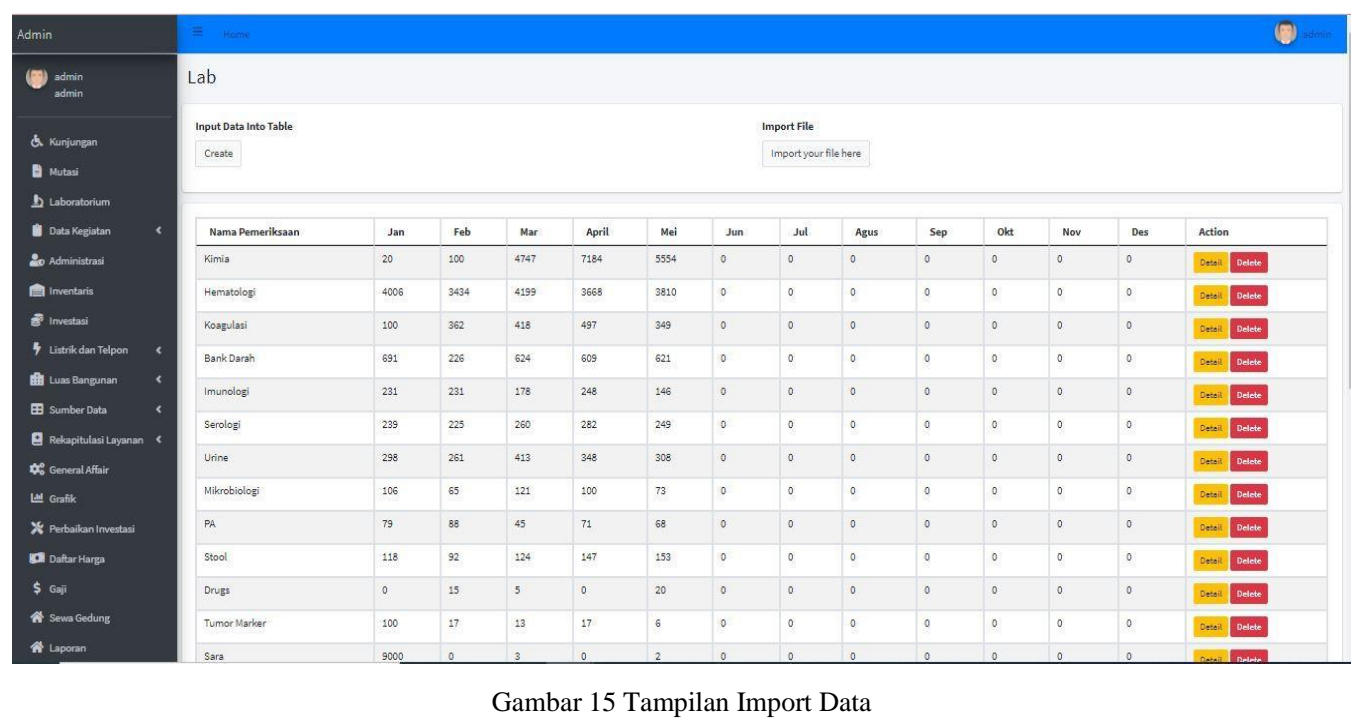

4) Tampilan Halaman Form Tambah Data: Gambar 16 adalah contoh adalah tampilan yang akan muncul saat user mengklik tombol create. Ketika user mengklik tombol create, akan muncul pop-up yang berisi form yang harus diisi untuk menambahkan data ke dalam tabel. Setelah user mengisi form untuk input data, terdapat tombol submit untuk memasukkan inputan user ke dalam tabel. 


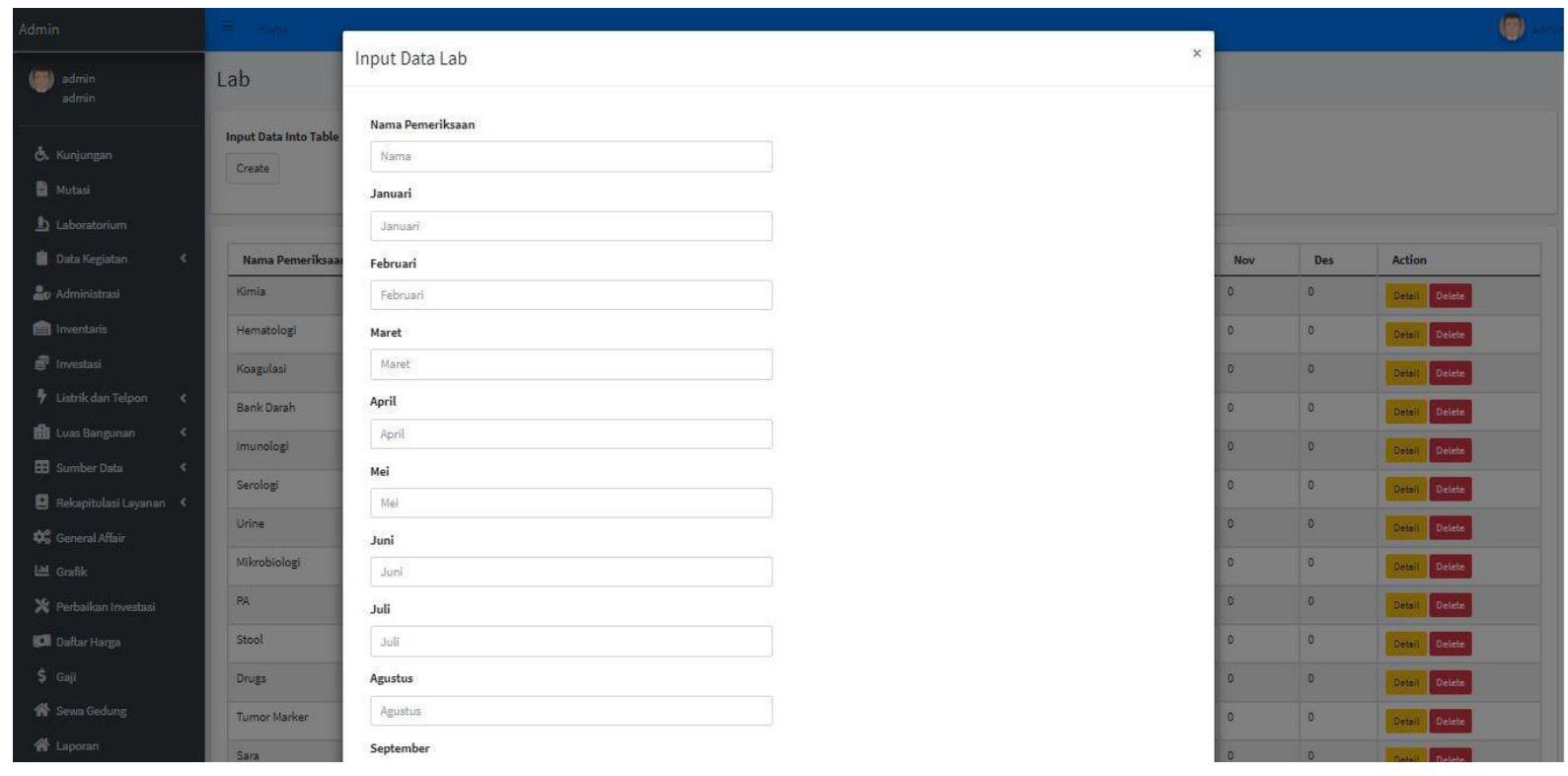

Gambar 16 Tampilan Tambah Data

5) Tampilan Halaman Detail Data: Gambar 17 adalah tampilan untuk halaman detail data. Halaman detail akan menampilkan detail dari data yang tampil di tabel. Di halaman detail ini terdapat tombol edit data yang jika di klik oleh user akan memunculkan form untuk mengisi inputan untuk mengubah data.

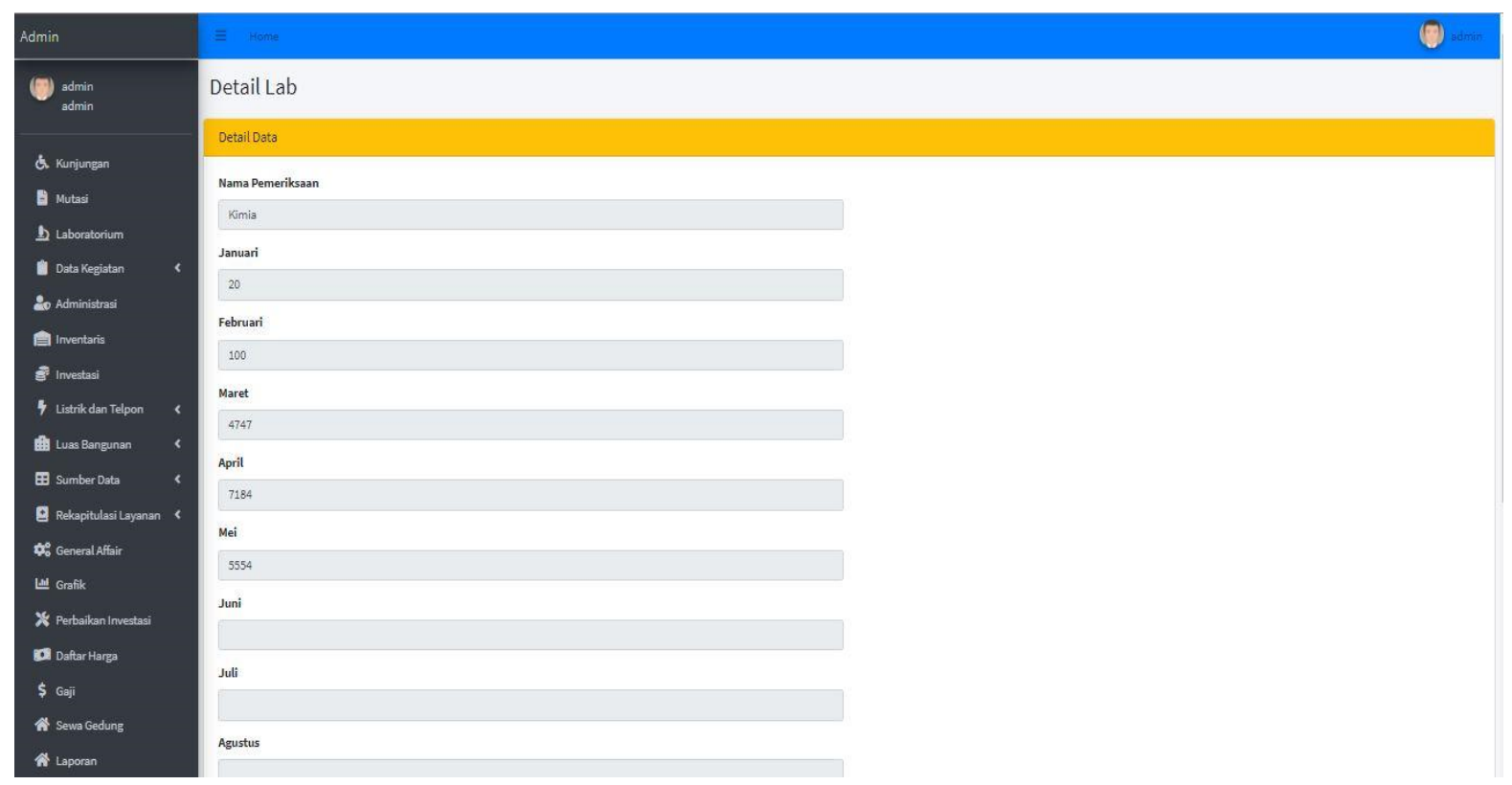

Gambar 17 Tampilan Detail Data

6) Tampilan Halaman Ubah Data: Gambar 18 adalah tampilan yang akan muncul saat user mengklik tombol edit data. Ketika user mengklik tombol edit, akan muncul pop-up yang berisi form yang harus diisi untuk mengubah data di dalam tabel. 


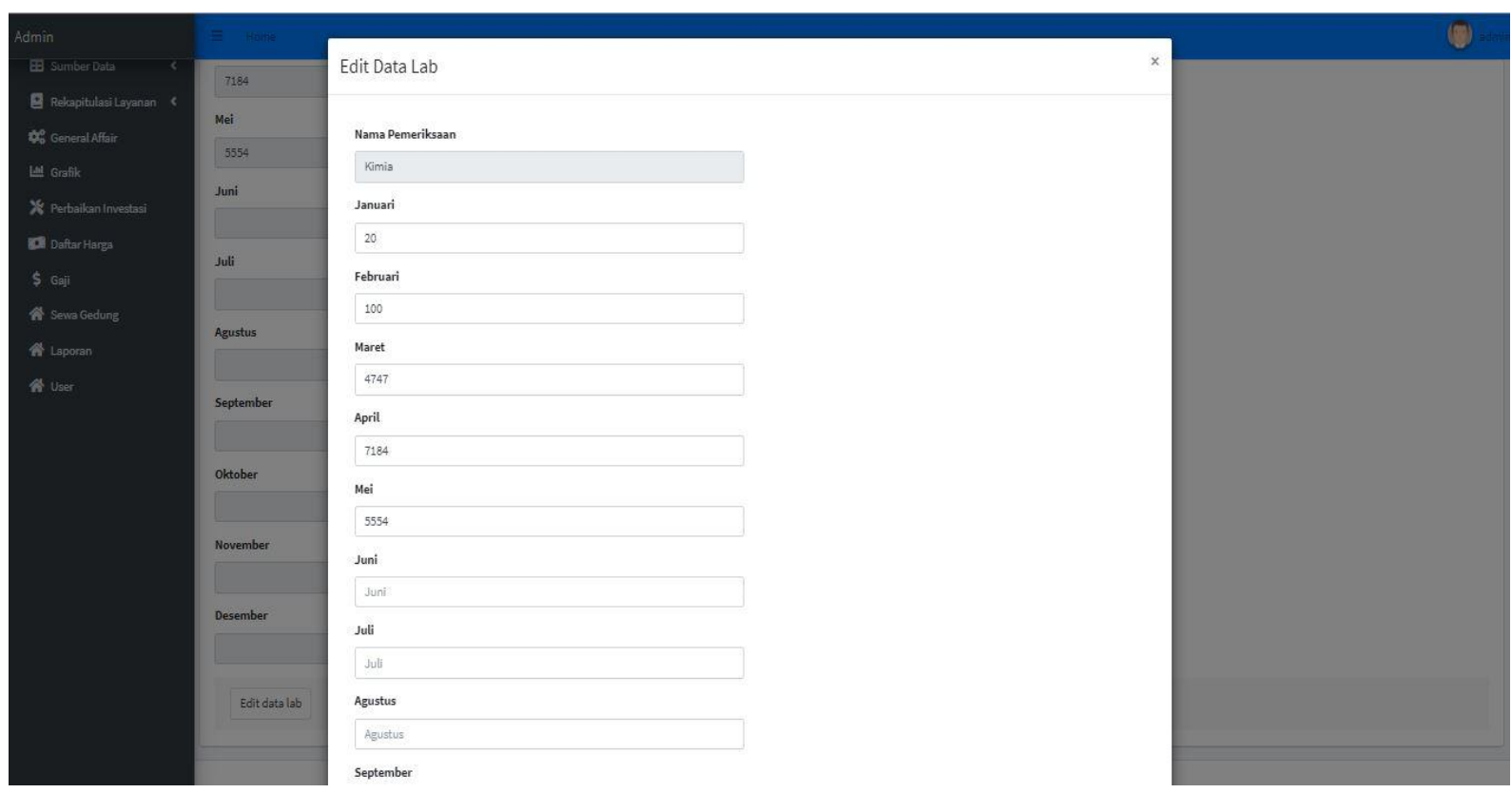

Gambar 18 Tampilan Ubah Data

7) Tampilan Halaman Laporan: Gambar 19 adalah halaman yang menampilkan daftar mutasi barang yang sudah dikerjakan. Halaman ini juga akan menampilkan total seluruh mutasi dari jumlah mutasi yang dilakukan ,jumlah total mutasi dan rata-rata dari jumlah mutasi dan disertakan oleh grafik pie chart.

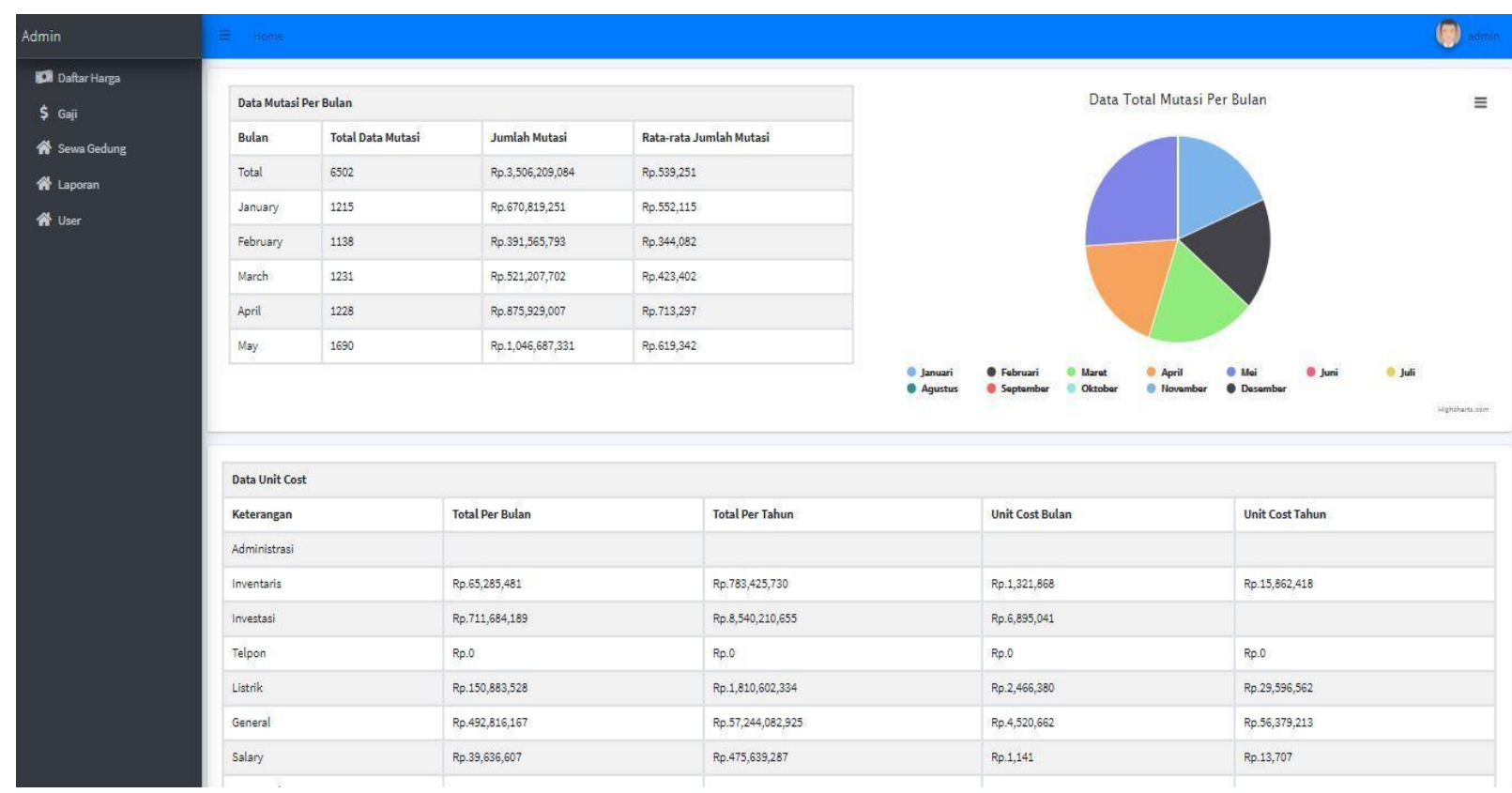

Gambar 19 Tampilan Halaman Laporan

8) Tampilan Halaman Kegiatan: Pada halaman data kegiatan berisikan halaman Gambar 20, Gambar 21, dan Gambar 22. Halaman data kegiatan ini memiliki fitur import serta memiliki tombol detail pada setiap halaman.

- BOR (Bed Occupation Rate) yaitu persentase pemakaian tempat tidur pada waktu tertentu. Nilai BOR ideal adalah $60-85 \%$. Rumus BOR dapat dihitung dengan rumus berikut: 


$$
B O R=\frac{\text { JumlahHP } * 100}{\text { JumlahKTT*31 }}
$$

- LOS (Length Of Stay) adalah rata-rata lama pasien dirawat dirumah sakit. Rumus LOS ditulis dengan rumus berikut:

$$
L O S=\frac{\text { JumlahLD }}{\text { JumlahPKeluar }}
$$

- TOI (Turn Over Interval) adalah rata-rata hari dimana tempat tidur tidak ditempati dari telah terisi hingga saat terisi selanjutnya. Nilai ideal tempat tidur kosong adalah $1-3$ hari. TOI dapat dihitung dengan rumus berikut:

$$
T O I=\frac{\text { JumlahKTT*31-JumlahHP }}{\text { JumlahPKeluar }}
$$

- BTO (Bed Turnover Rate) adalah frekuensi pemakaian tempat tidur dalam satu periode. Idealnya dalam setahun, satu tempat tidur rata-rata dipakai sebanyak 40-50 kali. Rumus BTO dapat dihitung dengan rumus berikut: [19]

$$
\text { BTO }=\frac{\text { JumlahP.Keluar }}{\text { JumlahKTT }}
$$

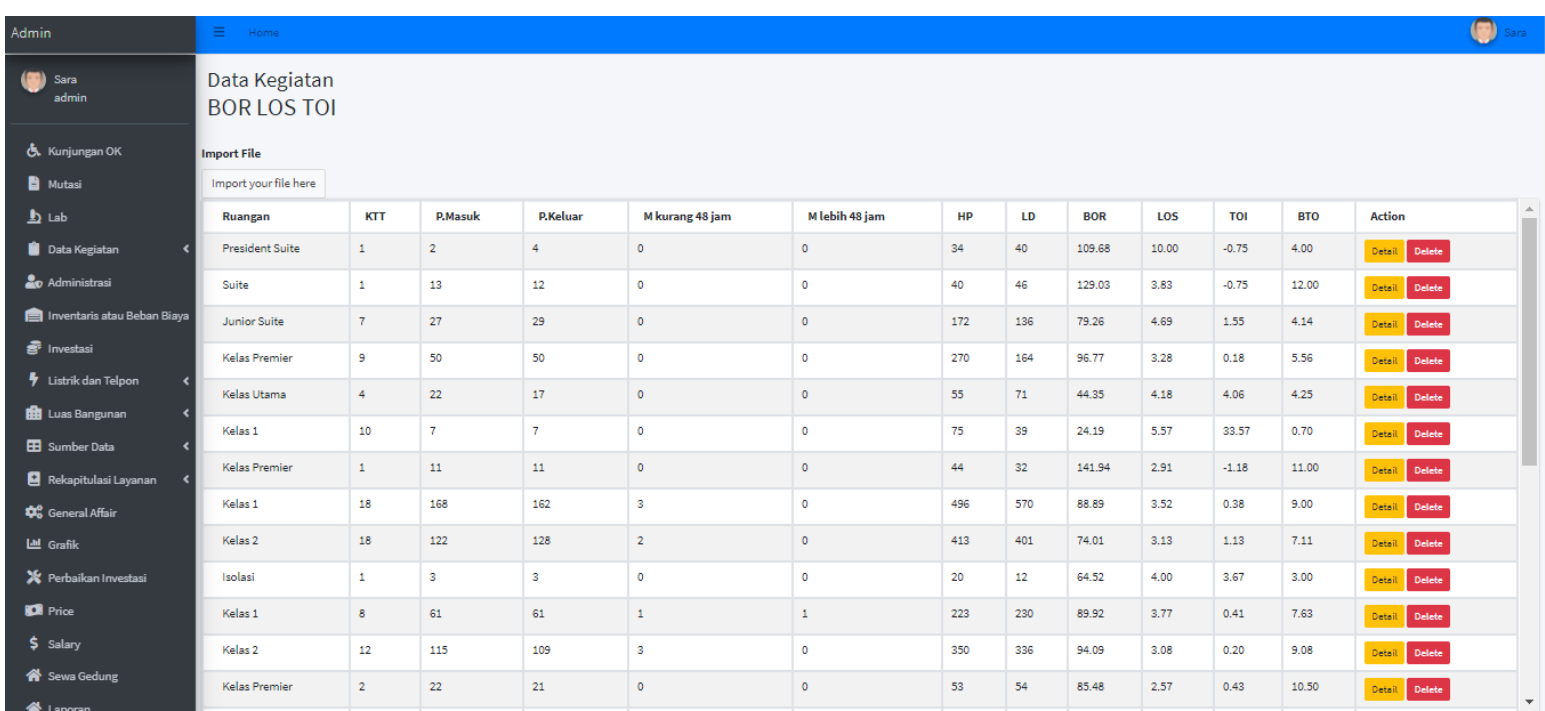

Gambar 20 Halaman Data Kegiatan - BOR LOS TOI 


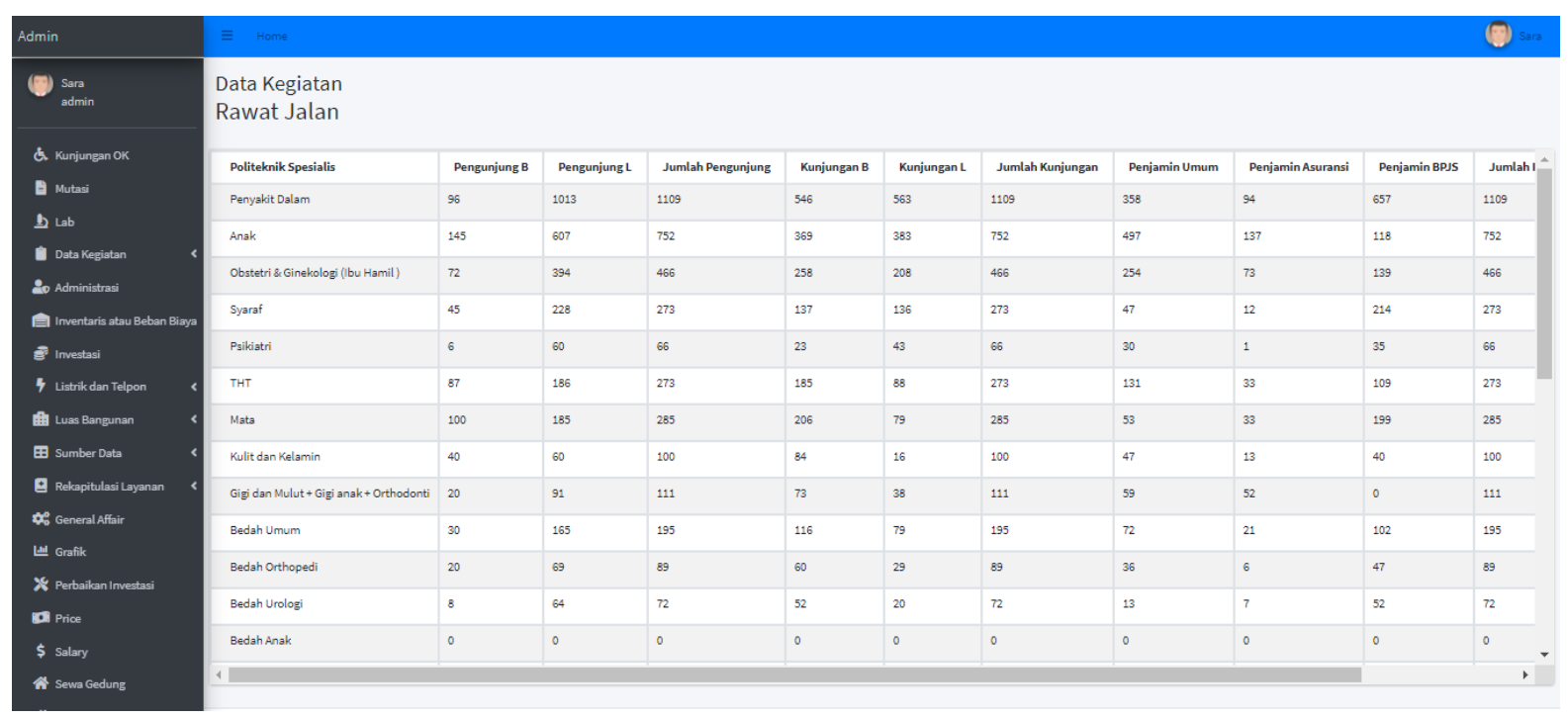

Gambar 21 Halaman Data Kegiatan - Rawat Jalan

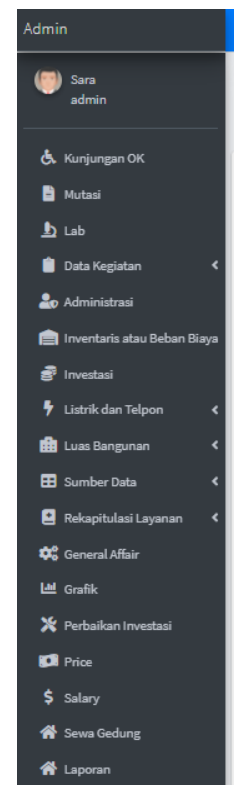

Data Kegiatan

IGD

\begin{tabular}{|c|c|c|c|c|c|c|c|c|c|c|c|c|c|c|c|c|}
\hline Kriteria & Jan & Feb & Mar & April & Mei & Juni & Juli & Ags & Sep & okt & Nov & Des & \begin{tabular}{|l} 
Jumlah \\
\end{tabular} & Persen & Rerata & Action \\
\hline Ban & 1788 & $\circ$ & 0 & 0 & 0 & o & 0 & 0 & $\circ$ & $\circ$ & $\circ$ & $\circ$ & 1788 & $61.00 \%$ & 149.00 & Deseri Dodete \\
\hline Lams & 1146 & 0 & 0 & 0 & 0 & 。 & 0 & 0 & $\circ$ & 0 & 。 & 。 & 1146 & 39.0096 & 95.50 & Destail Dedeter \\
\hline Laki-1aki & 1287 & 0 & 。 & 。 & 。 & 。 & 。 & 0 & 。 & 。 & 。 & 。 & 1287 & $44.09 \%$ & 107.25 & Deseril Dedete \\
\hline Perempuan & 1647 & 0 & 0 & 0 & 0 & $\circ$ & 。 & 0 & 0 & 0 & o & 。 & 1647 & $56.00 \%$ & 137.25 & Deseril Dodete \\
\hline Pulang & 1 & 。 & 。 & 。 & 。 & 。 & 。 & 。 & 。 & 。 & 。 & 。 & 1 & $17.00 \%$ & 0.08 & Descail Dodecte \\
\hline Dirswat & 1 & $\circ$ & 。 & 0 & 0 & 。 & 0 & 0 & $\circ$ & 0 & 0 & 。 & 1 & $17.00 \%$ & 0.08 & Deseail Dodete \\
\hline Dirjukk & 1 & 。 & 。 & 。 & 。 & 。 & 。 & 。 & 。 & 。 & 。 & 。 & 1 & $17.00 \%$ & 0.08 & Destail Dedecte \\
\hline Meningsal & 1 & 0 & 0 & 0 & 0 & $\circ$ & 0 & 0 & 0 & 0 & 0 & 。 & 1 & $17.00 \%$ & 0.08 & Destail Dedete \\
\hline Desath on Arrvival (100A) & 1 & 。 & 。 & 。 & 。 & 。 & 。 & 0 & 。 & 。 & 。 & 。 & 1 & $17.00 \%$ & 0.08 & Destail Dodecte \\
\hline APS & 1 & 0 & 0 & 0 & 0 & $\circ$ & 0 & 0 & $\circ$ & 0 & 0 & 。 & 1 & $17.00 \%$ & 0.08 & Destail Dadete \\
\hline Bedsh & 1 & 。 & 。 & 。 & 。 & 。 & 。 & 0 & 。 & 。 & 。 & 。 & 1 & 20.0096 & 0.08 & Destail Dodecte \\
\hline Dalam & 1 & 0 & 0 & 0 & 0 & 0 & 0 & 0 & 0 & 0 & 0 & 0 & 1 & $20.00 \%$ & 0.08 & Destail Deleter \\
\hline Anak & 1 & 。 & 0 & 。 & 。 & 。 & 。 & 。 & 。 & 。 & 。 & 。 & 1 & $20.00 \%$ & 0.08 & Destail Dedecte \\
\hline Martenity & 1 & 0 & 0 & 0 & 0 & 0 & 0 & 0 & $\circ$ & 0 & 0 & 0 & 1 & 20.0096 & 0.08 & Deseal Dobeter \\
\hline & & & & & & & & & & & & & & & & $\ldots$ \\
\hline
\end{tabular}

Gambar 22 Halaman Data Kegiatan - IGD

\section{B. Pengujian Aplikasi Web}

Tahapan pengujian aplikasi web menggunakan teknik black box testing. Teknik ini berfokus pada fungsi perangkat lunak tanpa mengetahui isi dalamnya dan bertujuan untuk mengetahui apakah aplikasi sudah berjalan sesuai dengan kebutuhan dan tujuan awal dari pembuatan aplikasi web. Hasil pengujian dapat dilihat pada Tabel 1[20]. 
TABEL 1

HASIL PENGUJIAN WEBSITE

\begin{tabular}{|c|c|c|c|c|}
\hline No & Test Case & Hasil yang diharapkan user & Hasil yang didapatkan dari pengujian & Keterangan \\
\hline 1 & $\begin{array}{l}\text { Respon halaman, jika import } \\
\text { file excel yang sudah } \\
\text { dilakukan penomoran } \\
\text { berhasil }\end{array}$ & $\begin{array}{l}\text { Menampilkan validasi "Import } \\
\text { Berhasil" }\end{array}$ & Menampilkan validasi :Import Berhasil" & Berhasil \\
\hline 2 & $\begin{array}{l}\text { Respon halaman, jika file } \\
\text { excel yang diimport salah }\end{array}$ & $\begin{array}{l}\text { Menampilkan validasi } \\
\text { Salah", }\end{array}$ & Menampilkan validasi "File Salah" & Berhasil \\
\hline 3 & $\begin{array}{l}\text { Respon halaman, jika } \\
\text { melakukan import tanpa file }\end{array}$ & $\begin{array}{l}\text { Menampilkan validasi "Import } \\
\text { File Here" }\end{array}$ & Menampilkan validasi "Import File Here" & Berhasil \\
\hline 4 & $\begin{array}{l}\text { Respon halaman, jika inputan } \\
\text { data tidak diisi }\end{array}$ & Menampilkan validasi & $\begin{array}{l}\text { Menampilkan validasi yang sesuai pada } \\
\text { inputan }\end{array}$ & Berhasil \\
\hline 5 & $\begin{array}{l}\text { Respon halaman, jika inputan } \\
\text { terisi dan sesuai }\end{array}$ & $\begin{array}{l}\text { Menampilkan validasi } \\
\text { Telah Disimpan"” }\end{array}$ & $\begin{array}{l}\text { Menampilkan Validasi "Data Telah } \\
\text { Disimpan" }\end{array}$ & Berhasil \\
\hline 6 & $\begin{array}{l}\text { Respon halaman, jika edit } \\
\text { data tidak terisi dan tidak } \\
\text { sesuai }\end{array}$ & Menampilkan validasi & $\begin{array}{l}\text { Menampilkan validasi yang sesuai dengan } \\
\text { masing-maisng inputan }\end{array}$ & Berhasil \\
\hline 7 & $\begin{array}{l}\text { Respon halaman, jika edit } \\
\text { data sudah sesuai dan terisi }\end{array}$ & $\begin{array}{l}\text { Menampilkan validasi "Data } \\
\text { Berhasil Diubah" }\end{array}$ & $\begin{array}{l}\text { Menampilkan validasi "Data Berhasil } \\
\text { Diubah" }\end{array}$ & Berhasil \\
\hline 8 & $\begin{array}{l}\text { Respon halaman, jika hapus } \\
\text { data }\end{array}$ & $\begin{array}{l}\text { Menampilkan validasi "Data } \\
\text { Telah Dihapus" }\end{array}$ & $\begin{array}{l}\text { Menampilkan validasi "Data Telah } \\
\text { Dihapus" }\end{array}$ & Berhasil \\
\hline 9 & $\begin{array}{l}\text { Jika inputan } \\
\text { dimasukkan kata }\end{array}$ & Menampilkan angka & Hanya menampilkan angka saja & Berhasil \\
\hline 10 & $\begin{array}{l}\text { Jika melakukan import kedua } \\
\text { kali dengan file yang sama }\end{array}$ & $\begin{array}{l}\text { Data akan terupdate jika memiliki } \\
\text { data yang sama dan akan } \\
\text { bertambah jika belum memiliki } \\
\text { data }\end{array}$ & $\begin{array}{l}\text { Data akan terupdate jika memiliki data } \\
\text { yang sama dan akan bertambah jika data } \\
\text { sebelumnya belum ada atau berbeda }\end{array}$ & Berhasil \\
\hline
\end{tabular}

\section{User Acceptance}

Pengujian ini dilakukan oleh user yang berinteraksi dengan sistem dan melakukan pengujian apakah fungsi dapat berjalan sesuai dengan kebutuhan. Pengujian ini terdapat 10 pertanyaan yang berhubungan dengan website berkaitan dengan fitur dan kemudahan pada website. Pada pengujian ini akan dilakukan oleh pegawai pihak rumah sakit dan dinilai berdasarkan 5 kategori yaitu sangat setuju (ss), setuju (s), cukup setuju(cs), kurang setuju(ks) dan tidak setuju(ts). Hasil User Acceptance Test dapat dilihat pada Tabel 2 [21].

TABEL 2.

HASIl PenguJian USER ACCEPTANCE

\begin{tabular}{|c|c|c|c|c|c|c|}
\hline No & Pertanyaan & SS & $\mathbf{S}$ & $\mathbf{C S}$ & $\mathbf{K S}$ & TS \\
\hline 1 & Apakah fitur import file berfungsi dengan baik? & & & 1 & & \\
\hline 2 & Apakah fitur tambah data berfungsi dengan baik? & & 1 & & & \\
\hline 3 & Apakah fitur hapus data berfungsi dengan baik? & & & 1 & & \\
\hline 4 & Apakah fitur ubah data berfungsi dengan baik? & & & 1 & & \\
\hline 5 & Apakah aplikasi ini bermanfaat bagi pengguna? & 1 & & & & \\
\hline 6 & $\begin{array}{l}\text { Secara keseluruhan apakah penggunaan pada aplikasi pengelolaan data ini } \\
\text { memuaskan? }\end{array}$ & & 1 & & & \\
\hline 7 & Apakah aplikasi pengelolaan data ini mudah digunakan (user friendly)? & & & 1 & & \\
\hline 8 & Apakah aplikasi pengelolaan data ini memenuhi kebutuhan? & & & 1 & & \\
\hline 9 & $\begin{array}{l}\text { Apakah informasi yang disediakan oleh aplikasi pengelolaan data ini mudah } \\
\text { dimengerti? }\end{array}$ & & 1 & & & \\
\hline 10 & Apakah aplikasi pengelolaan data ini dapat mempermudah pekerjaan pegawai? & 1 & & & & \\
\hline
\end{tabular}




\section{Pengujian Aplikasi Web}

Tahap pengujian aplikasi web dilakukan untuk mengetahui apakah UI/UX pada aplikasi web telah sesuai dengan standar permintaan dari pihak rumah sakit. Pada tahap pengujian ini, dilakukan trial aplikasi kepada pihak rumah sakit untuk menunjukkan perkembangan pembuatan tampilan aplikasi web melalui Zoom Meeting, yang dimana untuk melakukan trial ini membutuhkan persetujuan terlebih dahulu dengan pihak rumah sakit. Pada tahap ini juga pihak rumah sakit bisa memberi masukan mengenai tampilan yang sudah dibuat untuk diperbaiki dan selanjutnya masuk ke tahap perbaikan.

\section{E. Perbaikan UI/UX}

Perbaikan yang dilakukan pada desain tampilan web ini adalah perbaikan di sisi $U I / U X$. Perbaikan $U I / U X$ didapatkan dari hasil penilaian langsung dari pihak rumah sakit. Proses penilaian dilakukan dengan cara mengirimkan screenshot tampilan ke pihak rumah sakit, lalu pihak rumah sakit akan memberikan sedikit masukan untuk perbaikan UI/UX. Berikut adalah perbaikan yang telah dilakukan terhadap antarmuka website:

1) Perbaikan $U I / U X$ pada tampilan (antarmuka) halaman home: Mengubah tampilan menu daftar laporan, dengan memindahkan тепи-тепи daftar laporan yang sebelumnya diletakkan di tengah halaman home menjadi diletakkan di sidebar menu.

2) Perbaikan UI/UX pada desain warna dasar tampilan website: Perbaikan ini dilakukan dengan tujuan supaya pengguna bisa membedakan tampilan antara user admin dengan user employee hanya dengan melihat warna dasar tampilan website.

3) Perbaikan UI/UX pada tampilan halaman laporan: Menambahkan detail data gaji dengan tampilan yang menyerupai slip gaji pada umumnya.

4) Perbaikan $U I / U X$ pada tampilan format data: Penambahan format pada data yang berbentuk tanggal dan angka agar mudah untuk dipahami oleh pengguna.

\section{F. Penilaian Hasil Perbaikan}

Penilaian dari perbaikan terakhir dilakukan pada tampilan web. Penilaian hasil perbaikan tampilan web menggunakan teknik rating dari Post-Study System Usability Questionnaire (PSSUQ) versi tiga dengan jumlah 16 soal dan digunakan untuk memperkirakan tingkat kepuasan user pengguna terhadap tampilan web. PSSUQ akan menghasilkan empat penilaian secara menyeluruh serta tiga sub skala. Tabel 3 adalah penjabaran dari PSSUQ.

TABEL 3.

JENIS PENILAIAN PSSUQ

\begin{tabular}{ll}
\hline \multicolumn{1}{c}{ Jenis Penilaian } & \multicolumn{1}{c}{ Keterangan } \\
\hline Overall & Didapat dari rata-rata pertanyaan nomor 1 sampai 16 \\
\hline System quality (sysqual) & Didapat dari rata-rata pertanyaan nomor 1 sampai 6 \\
\hline Information quality (infoqual) & Didapat dari rata-rata pertanyaan nomor 7 sampai 12 \\
\hline Interface quality (intqual) & Didapat dari rata-rata pertanyaan nomor 13 sampai 16 \\
\hline
\end{tabular}

Berikut rumus yang digunakan untuk menghitung rata-rata sub skala:

$$
\text { Sub skala }=\frac{\text { jumlahskorpenilaianrespondendarisetiap } p_{\text {skala }}}{\text { jumlahnomoritempertanyaandarisetiap } p_{\text {skala }}}
$$

Hasil penilaian tampilan web menggunakan PSSUQ sebelum perbaikan dan sesudah perbaikan dijabarkan pada tabel 4 dan tabel 5 berikut ini:

TABEL 4

HASIL PSSUQ SEBELUM DILAKUKAN PERBAIKAN

\begin{tabular}{cc}
\hline Skala PSSUQ & Rata-Rata \\
\hline Overall & 3.75 \\
\hline Sysqual & 4.67 \\
\hline Infoqual & 3.33 \\
\hline Intqual & 3 \\
\hline
\end{tabular}


Berikut hasil dari perhitungan rata-rata PSSUQ sebelum Perbaikan pada Tabel 4:

$$
\begin{aligned}
& \text { Overall }=\frac{5+6+5+4+4+4+3+4+3+4+3+3+3+3+3+3}{16}=3.75 \\
& \text { Sysqual }=\frac{5+6+5+4+4+4}{6}=4.67 \\
& \text { Infoqual }=\frac{3+4+3+4+3+3}{6}=3.33 \\
& \text { Intqual }=\frac{3+3+3+3}{4}=3
\end{aligned}
$$

TABEL 5.

HASIL PSSUQ SeTELAh DilakUKAN PERBaikan

\begin{tabular}{cc}
\hline Skala PSSUQ & Rata-Rata \\
\hline Overall & 5.75 \\
\hline Sysqual & 5.67 \\
\hline Infoqual & 5.67 \\
\hline Intqual & 6 \\
\hline
\end{tabular}

Berikut hasil dari perhitungan rata-rata PSSUQ setelah perbaikan pada tabel 5 :

$$
\begin{aligned}
& \text { Overall }=\frac{6+6+5+6+5+6+5+6+5+6+5+7+6+6+6+6}{16}=5.75 \\
& \text { Sysqual }=\frac{6+6+5+6+5+6}{6}=5.67 \\
& \text { Infoqual }=\frac{5+6+5+6+5+7}{6}=5.67 \\
& \text { Intqual }=\frac{6+6+6+6}{4}=6
\end{aligned}
$$

\section{SIMPULAN}

Berdasarkan hasil dari pengujian BlackBox Testing dan User Acceptance Test dapat disimpulkan bahwa $20 \%$ menyatakan sangat setuju, 30\% menyatakan setuju, dan 50\% menyatakan cukup setuju dengan fungsi fitur dan kemudahan yang diberikan seperti informasi yang ditampilkan, penggunaan aplikasi yang mudah digunakan serta mempermudah pekerjaan pegawai. Selanjutnya dengan adanya website ini dapat memberikan kemudahan kepada pegawai dalam mengolah data, memasukkan data, mengubah data, dan menghapus data. Website ini juga dapat memberikan informasi yang dapat mudah dibaca dan dimengerti oleh pegawai. Berdasarkan hasil dari perancangan dan penilaian PSSUQ maka didapat kesimpulan yaitu perancangan dan penilaian $P S S U Q$ sebelum dan sesudah perbaikan diatas dapat dikatakan telah memenuhi standar permintaan dari pihak rumah sakit dengan cara membuat antarmuka yang simpel dan mudah dipahami dalam pengelolaan data. Tampilan dapat dikatakan telah memenuhi standar yang diperoleh dari hasil kuesioner PSSUQ yang diisi oleh PIC dari pihak rumah sakit. Dari hasil kuesioner, didapatkan perhitungan rata-rata dari setiap sub skala sebelum perbaikan dan sesudah perbaikan. Hasil perhitungan rata-rata sesudah melakukan perbaikan telah meningkat dari hasil perhitungan rata-rata sebelum perbaikan. Adapun rata-rata dari setiap sub skala yang pertama adalah overall dari 3.75 menjadi 5.75, sysqual dari 4.67 menjadi 5.67, infoqual dari 3.33 menjadi 5.67, dan yang terakhir intqual dari 3 menjadi 6. Setelah itu, pihak rumah sakit mudah untuk mendapatkan informasi terkait laporan-laporan yang ditampilkan di dalam web. Maka dari itu perbaikan terakhir dari sisi antarmuka dapat disimpulkan telah memenuhi tujuan penilaian standar dari aplikasi web untuk rumah sakit.

\section{UCAPAN TERIMA KASIH}

Puji Syukur kepada Tuhan Yang Maha Esa, atas terselesainya jurnal ini. Dalam menyelesaikan pengerjaan laporan ini, banyak tantangan dan masalah yang kami hadapi dan semua tidak terlepas dari bantuan dan dukungan dari dosen pembimbing, pihak rumah sakit, dan lingkungan sekitar. Kami mengucapkan terima kasih kepada Rumah Sakit Santosa Kopo Bandung yang telah memberikan kesempatan untuk melakukan penelitian dari pengumpulan data hingga terbuat aplikasi web, Fakultas Teknologi Informasi Universitas Kristen Maranatha yang telah memberikan kesempatan untuk tahapan Tugas Akhir dan telah memfasilitasi proses administrasi yang diperlukan untuk penelitian ini. 


\section{DAFTAR PUSTAKA}

[1] Anggaeni and Irviani, Pengantar Sistem Informasi, Yogyakarta: CV. Andi Offset, 2017.

[2] R. Abdulloh, 7 in 1 Pemrograman Web Untuk Pemula, Jakarta: Elex Media Komputindo, 2018.

[3] D. Setiawan, Buku Sakti Pemrograman Web : HTML, CSS, PHP, MySQL \& Javascript, Yogyakarta: Anak Hebat Indonesia, 2017.

[4] B. S. Nugraha, "Rancang Bangun Aplikasi Pengelolaan Data Hasil Penelitian dan Jurnal Berbasis Web pada STIKES Yayasan Rumah Sakit Dr. Soetomo Surabaya," Institut Bisnis dan Informatika STIKOM Surabaya, Surabaya, 2014.

[5] "Santosa Hospital Kopo Bandung," [Online]. Available: https://www.santosa-hospital.com/v1/hospital/SHBK/profile. [Accessed 30 Oktober 2020].

[6] I. D. SHBC, "Santosa Hospital Bandung Kopo - Friendly \& Caring," Santosa Hospital Bandung, 2020. [Online]. Available: https://www.santosahospital.com/v1/hospital/SHBK/profile. [Accessed 26 Oktober 2020].

[7] M. D. Ariawan, A. Triayudi and I. D. Sholihati, "Perancangan User Interface Design dan User Experience Mobile Responsive pada Website Perusahaan," Jurnal Media Informatika Budidarma, vol. 4, no. 1, pp. 161-166, 2020.

[8] D. F. D. Putra, "Evaluasi dan Pengembangan Knowledge Management System Menggunakan Post-Study Usability Questionnaire (PSSUQ)," Jurnal Rekayasa Informasi Swadharma (JRIS), vol. 1, no. 1, pp. 9-13, 2021.

[9] Rizky, "Medium," 15 Januari 2019. [Online]. Available: https://medium.com/dot-intern/sdlc-metode-waterfall-5ae2071f161d.. [Accessed 20 November 2020].

[10] J. Enterprise, HTML, PHP dan MySQL untuk Pemula, Jakarta: Elex Media Komputindo, 2018.

[11] A. Amelia, "EVALUASI ANTARMUKA DAN PENGALAMAN PENGGUNA WEBSITE SERTA CODE REFACTORING PADA WEBSITE EKOSAN," Jurnal Ilmiah Komputer dan Informatika (KOMPUTA), vol. 5, no. 2, pp. 67-74, 2016.

[12] E. Junirianto, Pemrograman Web Dengan Framework Laravel, WADE Group, 2018.

[13] Y. K, "Laravel Framework: Pengertian, Keunggulan \& Tips untuk Pemula," NiagaHoster, 28 Juni 2019. [Online]. Available: https://www.niagahoster.co.id/blog/laravel-adalah/. [Accessed 1 November 2020].

[14] Laravel. [Online]. Available: https://laravel.com/docs/8.x/. [Accessed 27 Oktober 2020].

[15] tutorialpoint, "https://www.tutorialspoint.com," [Online]. Available: https://www.tutorialspoint.com/mvc_framework/index.htm.

[16] D. A. Hadi, "Pengertian Dan Cara Menggunakan Bootstrap," MalasNgoding, [Online]. Available: https://www.malasngoding.com/pengertian-dancara-menggunakan-bootstrap/. [Accessed 1 November 2020].

[17] omg, "https://www.omg.org," [Online]. Available: https://www.omg.org/spec/BPMN/2.0/About-BPMN/.

[18] V. Paradigm, "Visual Paradigm," [Online]. Available: https://www.visual-paradigm.com. [Accessed 15 Oktober 2020].

[19] Hosizah and Y. Maryati, Sistem Informasi Kesehatan II Statistik Pelayanan Kesehatan, Badan Pengembangan dan Pemberdayaan Sumber Daya Manusia Kesehatan, 2018.

[20] A. N. Afifa, "Rancang Bangun Aplikasi Penjualan Berbasis Web pada Percetakan Arbain Grafika Surabaya," Institut Bisnis dan Informatika Stikom Surabaya, Surabaya, 2018.

[21] T. Peham, "5 Types Of User Acceptance Testing," Usersnap, 18 Juni 2020. [Online]. Available: https://usersnap.com/blog/types-user-acceptancetests-frameworks/. [Accessed 15 April 2021]. 